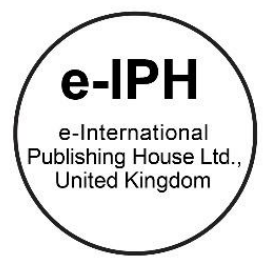

\title{
Urban Challenge Meets Hidden Potentials: Sustainable Development of El-Max Fishermen Village in Alexandria, Egypt
}

\author{
Dina Mamdouh Nassar ${ }^{*}$, Marwa Kamel El-Sayed 2 \\ ${ }^{1}$ Architectural Engineering Department, Faculty of Engineering, Alexandria University, Abu Qir St., Ibrahimiya, Alexandria 11432, Egypt \\ ${ }^{2}$ Architectural Engineering Department, Faculty of Engineering, Pharos University in Alexandria, El-Mahmoudiya Canal St., Smouha, Alexandria \\ 21523, Egypt
}

\begin{abstract}
Slum upgrading programs in Egypt focus mainly on the provision of basic services. Social and environmental needs are neglected resulting in critical issues. A community-driven approach is proposed to unfold the potential of slums by giving control of decisions and resources to the community.

The research examines El-Max Fishermen Village based on its potential due to its unique urban pattern and characteristics. It argues the ability of an informal settlement to reach sustainability goals through a community driven approach. It sets out a framework for urban development, emphasising social sustainability built on good governance and good urban management.

(c) 2016. The Authors. Published for AMER ABRA by e-International Publishing House, Ltd., UK. This is an open access article under the CC BYNC-ND license (http://creativecommons.org/licenses/by-nc-nd/4.0/).

Peer-review under responsibility of AMER (Association of Malaysian Environment-Behaviour Researchers), ABRA (Association of Behavioural Researchers on Asians) and CE-Bs (Centre for Environment-Behaviour Studies), Faculty of Architecture, Planning \& Surveying, Universiti Teknologi MARA, Malaysia.
\end{abstract}

Keywords: Slum Upgrading; Sustainable Urban Development; Community-Driven Development (CDD); Urban Management.

\section{Introduction}

Alexandria is the largest Mediterranean city in Egypt. More than three thousand years ago, a small fishing village called Rhacotis originated by the southern shores of the Mediterranean Sea. It is approximately at the same location of Alexandria's city centre. Alexander the Great (356-323 BC) picked this spot to become the new capital of the world. His city flourished throughout the Ptolemaic and Roman eras. Layers of history accumulated and built up its vast cultural identity. Despite Alexandria's ancient history and its modern worries, local Alexandrians, till this day consider the sea a basic component in their lives. A well-known Egyptian once stated; Alexandrians are like fish,

\footnotetext{
* Tel.: +20100-652-0526

E-mail address: dnassararch@yahoo.com
}

2398-4287 @ 2016. The Authors. Published for AMER ABRA by e-International Publishing House, Ltd., UK. This is an open access article under the CC BY-NC-ND license (http://creativecommons.org/licenses/by-nc-nd/4.0/).

Peer-review under responsibility of AMER (Association of Malaysian Environment-Behaviour Researchers), ABRA (Association of Behavioural Researchers on Asians) and CE-Bs (Centre for Environment-Behaviour Studies), Faculty of Architecture, Planning \& Surveying, Universiti Teknologi MARA, Malaysia.

DOI: http://dx.doi.org/10.21834/e-bpj.v1i4.95 
when taken away from the water, they die. The city has gravely developed throughout the years; successive historical epochs have come and gone. Remarkably, Alexandrians never lived far from the sea. Fishing was the job of the majority; their lives depended on the gifts of the sea. They firmly believe in keeping their line of work within the family. Even nowadays, many of them hold high college degrees; yet their career never changes.

Alexandria has three main fishermen communities. The oldest being the fishermen of Bahari, located near the city centre, followed by the Abu Qir fishermen on the East side, while the fishermen of El-Max lie on the west side. This came as a result of the city's long extended shoreline.

The research focuses on El-Max Fishermen Village; addressing their problems and exposing their hidden potentials. Despite their small population, El-Max fishermen's strong sense of community has been a mark of unique character in the midst of rough circumstances. They live in constant fear of eviction and environmental risks. Nevertheless, their distinct location deems them worthy of research as a case study of informal settlements in Egypt.

\section{Methodology and Aim of Work}

The paper addresses the problematic issue of slum upgrade. The aim is to state and evaluate the implications of ElMax case study within the framework of urban development. To promote its spatial regeneration, social and economic sustainability; the research analyses the area's morphology, deterioration, actions of municipal and state authorities, taking into consideration the strong sense of community portrayed by the fishermen as a catalyst for development. The methodology used in this research is based on analysing data collected on three levels; information gathered from the local authority with updated municipal and statistical information on El-Max fishermen village. Information collected from on-site observations, photography and videos. Moreover, information gathered from the field in the form of participatory discussions with individuals, families and fishermen. To yield better results and get sincere feedback, interviews were not used as a method of collecting data. The discussions took a more friendly approach ensuring the locals that their views and opinions are crucial for proposing actual solutions in the form of an upgrade project.

Analysing such various data led the authors to suggest an urban upgrade project based on a community-driven urban development programme; operating on the principles of transparency, participation, local empowerment, greater downward accountability, and enhanced local capacity. The proposed project aims to transform the negative image of the hazardous industrial area of El-Max through a community-driven urban development approach. The data collected and observation led the authors to discover hidden potentials in the area that can be taken advantage of to achieve sustainability goals.

The research is structured into three main sections. Section one describes the informal settlements in Egypt and clarifies the recent governmental approach to solving this issue through classification according to degrees of risk and scale of intervention. Section two presents the situation of informal settlements in Alexandria, focusing on the case study of El-Max Fishermen Village; discussing its problems and potentials. Section three proposes recommendations and an urban upgrade program for El-Max Fishermen Village. It also reviews the impact of institutional decisions and method of operation on the future social and economic stability of the locals.

\section{The Morphology of Informal Settlements in Egypt}

After the end of World War II, The Egyptian government's frequent policy changes faced challenges with the housing sector, which resulted in rural-to-urban migration in search of job opportunities and better standards of living. Housing problems have increasingly gained public exposure through both media coverage and scholarly debates. Previous research discussed how to reach the Millennium Development Goal of greatly improving the lives of at least 100 million slum dwellers by 2020 by proposing financial development programs and audits of planning regulations that can significantly improve living conditions within slum communities (Payne, 2005) (Bruce Ferguson, 2003). Meanwhile, members of informal settlements are facing problems; going through an on-going cycle of 
despair between disregard and becoming an issue of public opinion, to once more negligence and evacuation threats.

Social and public housing projects in the 1950s and 60s temporarily fulfilled the needs of the growing new urban society. Then, a general decline in the public housing sector was faced with the steady growth of governmental cooperative housing to cater the needs of the middle class. The policy of open economy in the 1980s led to a decrease in housing programs in general. Inflation in prices of building material restrained the government's ability to continue any housing programs in cities, thus opening the doors to the phenomena of private real estate investment. These phenomena triggered the informal housing problem in Alexandria as a direct response to fulfil the needs of lower and middle-class sectors. The government started continuing its housing programs in "New Cities", but did not react to the rapid urbanisation happening in cities like Cairo and Alexandria.

Considering the magnitude and scale of the housing deficit and the lack of concerted action or inadequate response of governmental authorities, there is no doubt of the role that informal housing plays in sheltering the millions of low-income families. Successive generation of governments have recognised this, and many approaches have been adopted in finding a solution to the dilemma. There are two types of approaches that the government takes in dealing with informal areas: preventative approaches that are meant to limit informal growth and interventionist approaches in which the government either improves or removes informal areas.

In general informal settlements in Egypt are called "slums". Article 78 of the 2014 Egyptian Constitution recognises 'ashwai'at' (The literal translation of which is random or unplanned areas) and requires the government to take steps to improve them. It refers to informal areas suffering from problems of accessibility, narrow streets, the absence of vacant land and open spaces, very high residential densities, and insufficient infrastructure and services ((GOPP), 2012). It takes one of the following forms; one form is squatting on the publicly owned land. This situation occurs on desert lands or public benefit areas in or around the cities. The other type is violating building regulations by offending land use regulations. This situation mainly occurs on privately owned agricultural lands or violating heights regulations inside the cities.

\section{The Informal Settlement Development Facility (ISDF)}

In 2008, Presidential Decree No. 305 issued the establishment of the ISDF (ISDF, 2012). It constitutes a funding facility that aims to develop and limit urban slums, as well as, provide urban planning strategies and basic infrastructure. The decree proceeds in coordination with concerned ministries and local public administrations, which in return provide the required information, expertise, and necessary aid.

The ISDF funds the six following programs:

Development of life-threatening areas

Development of inappropriate housing areas on state-owned property

Development of inappropriate housing areas of Central Authorities property

Development of inappropriate housing areas on privately owned property

Development of areas of Public Health Threat

Development of illegal housing areas

The ISDF re-defined informal settlements in Egypt into two categories, to resolve their problems. This classification divided them into unsafe areas and unplanned areas. According to (Khalifa, 2011); Unsafe areas are characterised by being subject to life threat, or having inappropriate housing, or exposed to health threat or tenure risks, while unplanned areas are principally characterised by its noncompliance to planning and building laws and regulations.

The informal settlements defined as unsafe are classified into four grades according to the severity of their situation. Thus, immediate intervention descending from the most to least, as following; areas that threaten life, areas of unsuitable shelter conditions, areas exposed to health risks and areas of instability due to the insecurity of tenures ((GOPP), 2012). 
The case of El-Max Fishermen Village is considered - according to the local slum administration authority; a (Grade Two). This classification means that the area is life-threatening because it is a floodplain area and with unsuitable shelter conditions. The buildings are made of makeshift materials, the sites unsuitable for building, and structures are ruined and unsafe. Therefore, the area is considered under risk. Dwellings must be relocated to safer provinces as a radical solution to ensure the protection and livelihoods of the citizens, and they are subject to immediate transfer to state-owned accommodation units. Alternatives include financial compensation, the use of existing or temporary housing units with the provision of land for self-building of new ones, or granting rent money for a limited period until the availability of newly constructed accommodation.

\section{Discussion and Analysis}

\subsection{Identifying Informal Settlements in Alexandria}

Alexandria has two cities under its jurisdiction forming a metropolis; with an urban lifestyle largely attracting rural or Bedouin citizens. This situation places a remarkable strain on housing supply in its six districts. Informal settlements appeared as a result of different inconvenient policies. They started as a demand for affordable housing that the government couldn't supply as the population was increasing rapidly. According to Alexandria SUP 2032 ((GOPP), 2012); the gap between supply and demand in the housing sector resulted in unplanned developments expanded in response to the general shortage of affordable urban residential building land and official low-cost rental housing in cities. Like any other place in Egypt, unplanned areas have fulfilled the needs of lower and lower-middle income residents. Alexandria was and still remains a magnet city to surrounding rural areas.

\subsection{Current Situation of El-Max Fishermen Village}

The following discussion is a result of studies carried out by the authors in the period from September 2013 to March 2014 (Nassar, Naguib, ElFakharany, \& Kamel, 2014) on El-Max Fishermen Village to list the problems and explore the potentials of development. The work also includes an update of the situation according to recent governmental action.

It will address in depth all physical, social and economic matters while demonstrating previous local efforts to upgrade the area. It will help support a community driven upgrade approach that will sustain the livelihood of the locals, thus reflecting positively on the city of Alexandria. While conducting the analyses, authors discovered hidden potentials that can creatively add attainments to locals and the city. The research will also summarise the findings in the suggested community-driven development upgrade program.

\subsubsection{Location, Size, and Statistics}

El-Max fishermen village shown in Fig. 1 is a small fishing community situated along an agricultural drain canal; called "El-Khanda'a", which makes its way through a small hill down to the Mediterranean Sea. It is located in ElAmriya District, west of Alexandria city. Its unique characteristics and environment inspired many to call it the "Egyptian Venice". It is located at the meeting point of the Nile's fresh water and the salinity of the sea. Small fishermen houses were built on the two banks of the canal at its tail end before it reaches the sea. They are characterised as simple shelters built mainly by brick from construction site remnants. They form levels on the hill stretching along one and a half kilometres of the canal. Fishing boats lie by the houses ready for going out into the sea and coming back with the everyday living. Unlike the fishermen of Bahari or Abu Qir; who have larger boats that could stay up to 4-6 days in the sea, El-Max fishermen rely on their small wooden boats. Approximately 15,000 inhabit El-Max area, with about 3,000 fishermen living there for more than 30 years. They faced mass displacement, despite the fact that they are responsible for $35 \%$ of the fish production in Alexandria. 


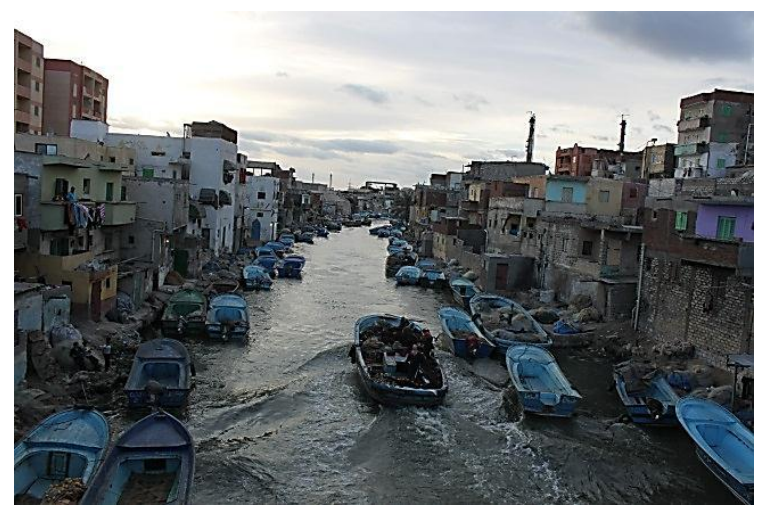

Fig. 1. View of El-Max Fishermen Village

Source: Authors

\subsubsection{Environmental, Social and Economic Risks}

El-Max Fishermen Village is situated north of an industrial zone, surrounded by petroleum companies which dispose of their industrial and chemical waste in the canal as shown in Fig. 2. Laws governing the environment demands to change filters frequently to avoid pollution issues. Furthermore, the Marriott Lake; which stretches south along Alexandria city borders, is suffering from pollution as a result of chemical and agricultural waste from surrounding companies. Nevertheless, significant parts of the lake were subject to filling (reclaimed land), thus dramatically affecting its eco-system. At present, the lake disposes the contaminated water into the Mediterranean Sea through two agricultural drainage canals; one of which is El-Max "El-Khanda'a" canal. Pollution caused a decline in the canal's fish habitats, which as a result, forced fishermen to sail out into the open sea to earn a living in extreme conditions. The prevailing wind direction in Alexandria is North to North West; therefore, the nearby industries do not pose any air pollution threats to the area. The satellite images in Fig. 3. Showing the industrial zone is south of El-Max.

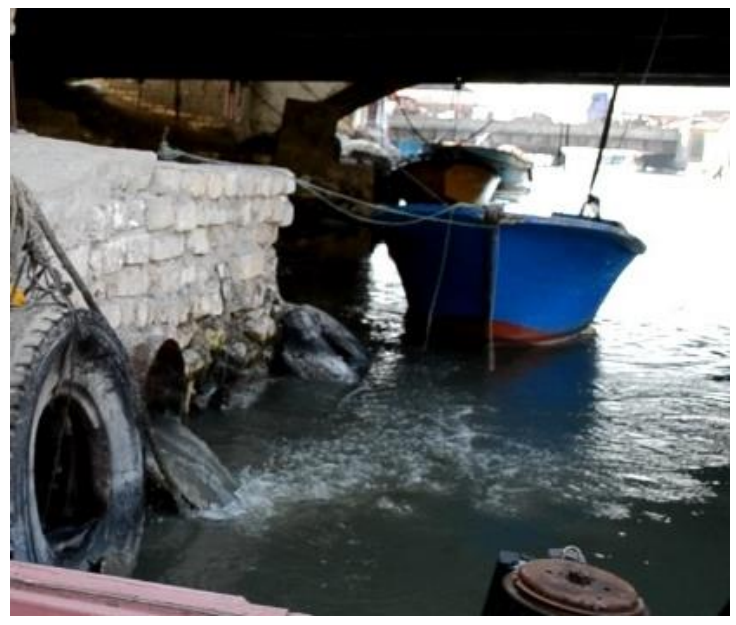

Fig. 2. Waste Disposal causing Canal Pollution Source: Authors 

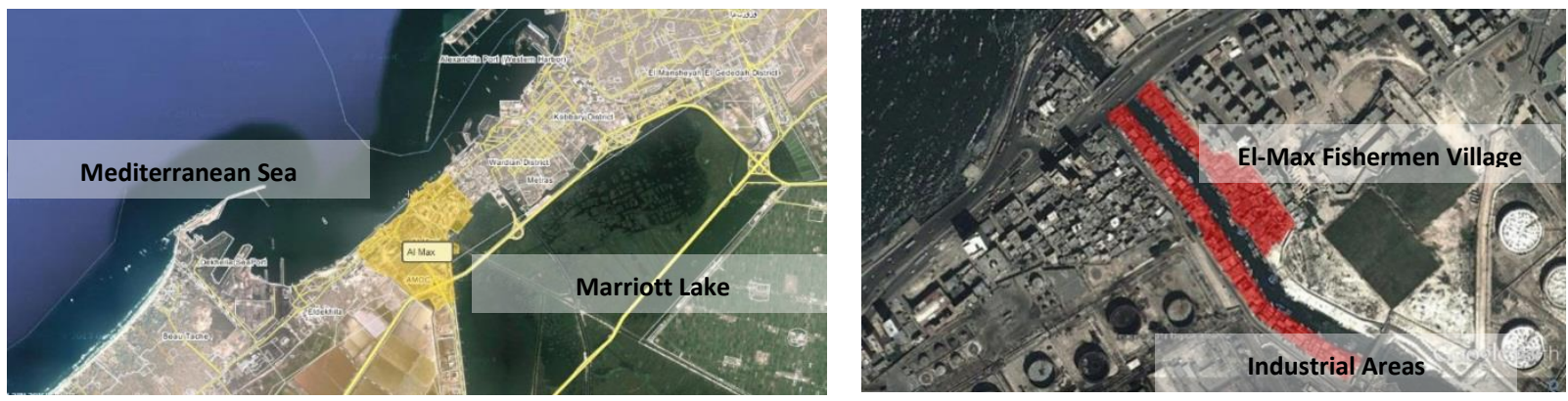

Fig. 3. Two Satellite Images of El-Max, area highlighted in yellow and the Fishermen Village highlighted in red Source: Authors

On one hand, this run down area suffer low education, low sanitary awareness, poverty and multiplying problems, still possesses what makes it a charming spot; namely its nature and simplicity. On the other hand, highly polluted water continues threatening their health, livelihood, and local economy.

Moreover, their only way out from the canal into the sea is beneath the vehicular bridge. Water current and speed accelerates at that point, causing some drowning incidents. The water level continues to rise and travelling that way has been named the "Death Path". Also, net piles were placed beneath the bridge forming a gate that prevents fishermen from going out into the sea without authorised permits. This Nets provided a way for the coastal guards to regulate the fishermen's movement according to a given schedule for entering and exiting the sea, to prevent smuggling and illegal immigration to and from Europe, especially after the 2011 Egyptian Revolution. However, the net piles led to a rise in the water level under the bridge and increasing threats of death.

\subsubsection{The Housing Situation}

By observation of the nature of the place and its physical structure, the characteristics can be deduced. They are a closed community with its culture, social structure and eventually its local economic system which is dependent on the environment. Earning a living is subject to the weather conditions and the gifts of the sea. Villagers' houses are primitive and poorly built with materials unable to withstand the coastal environment. Structural problems of coastal buildings ranging vastly from humidity, powerful wind currents, to heavy winter rains effects dwellings extensively fast. Such natural processes have been capable of physical deterioration and due to years of neglect, the physical core of the village is considered at risk. Villagers do not see that renovating and maintaining their homes is an issue to be discussed. They believe in the fact that a house is a place with mere physical structure, but a home encompasses some dynamic emotional and spiritual aspects, and the distinction between the two concepts are fundamental (Poor, 2015). According to them, more pressing livelihood matters require more attention. Even though decision makers in Alexandria favour the removal of the village and its relocation to a nearby place, the fishermen have developed a sense of community which relates to the notion of feeling belonged. The feeling of belonging to a place is important, and it means to have a personal relationship with the place of being and to feel like a part of the neighbourhood. Therefore, to achieve a self-sufficient community, it must be cohesive. Its well-being is important to be addressed and can be achieved through a more conducive living environment (Harlina Mohamad Ali, 2012).

However, according to the Informal Settlement Development Facility (ISDF) and due to its current circumstances, the area has been graded on the level of risk, a number two - unsafe informal area. 


\subsubsection{Previous Work at El-Max}

Gudran ${ }^{\dagger}$ Association for Art and Development is a coalition of artists, writers, photographers, directors, dramatists, and musicians motivated by art. From 2000 to 2008, Gudran worked with the people of El-Max to spread awareness through art as the means to establish a neutral ground for dialogue between the organisation and the villagers. They focused on fostering connections with the villagers through art workshops aimed at educating women, children, and teenagers. The initiative of this local NGO aimed to achieve a positive mutual cultural exchange between all participants through collective artistic work.

On the one hand, Gudran Art Association's intervention has shed some light on the situation of El-Max Fishermen Village. It attempted a development program based on motivating the youth in the active participation of restoration works, as well as, initiating workshops and artistic events to promote cultural exchange and encourage interaction amongst the community. In efforts of handing the responsibility to the villagers, Gudran trained a group of young members of the community maintenance skills to sustain the development. However, on the other hand, in 2013, amongst the discussions with the villagers resulted in the realisation that the previous efforts were not equally distributed in the village. They did not appreciate the short-term artistic-driven initiative, and they criticised how it did not tackle the critical issues causing the problems and affecting their daily lives. Instead, it just covered the surface that eventually faded away.

\subsubsection{Objectives and Hidden Potentials at El-Max Fishermen Village}

In aims of unfolding the true potentials of the area; making it not only an urban upgrade project for positive social, cultural and economic development, but also, a pollution free, self-sustained, safe and secure community, attracting tourists from places across the world.

As stated before, El-Max has been a home to the local fishermen for decades; therefore, the adaptability of this approach is directed towards social inclusion and participation while creating a model for other local communities. The process of public involvement in communities raises the levels of awareness and activism of residents concerning urban development (Jamalunlaili Abdullahab, 2015). It aims at using social capital as an asset to enhance positive social values towards a good living that contributes to the quality of life (Hazlina Hamdan, 2014). It also focuses on their growing demands and the ability to fulfil and manage them to generate efficient and effective results and to guarantee fair investment allocation plans (Ibrahim, 2012). The outcome will benefit local, city and regional levels, by providing security, a strong local economy, and environmental sustainability.

Site surveys by the authors uncovered two potentials that can revolutionise the area in a way that makes it, not only a sustainable community but also an attraction point for environmental and cultural tourism;

\section{A. The Archaeological Fortress of El-Max}

The Number of remaining archaeological sea defensive fortresses in Alexandria; called "Tawabi", have witnessed a remarkable era in the history of Egypt. With all the triumphs and failures, they held a major role in protecting the borders of Egypt and its coast against potential invaders.

Throughout history, a formidable wall has always been a fundamental protecting structure of major cities; especially along the shores of the Mediterranean Sea from Abu Qir to Port Said. Twenty-one historical fortresses were archaeologically recorded in and around the city of Alexandria. One of which is called the fortress of El-Max, "Tabiat El-Max El-Tahtaniah" shown in Fig. (4). (Aref, 2007)

An Islamic Archaeology official source stated that the fortress was built in the nineteenth century in conjunction with the construction of the canal itself, to protect it and guard the northern coast of Alexandria. This ancient abandoned building, although strategically located on a small island in the canal, locales do not see this fortress except as home to outlaws and drug abuse. The opportunity this place can give to the area must be added into the

\footnotetext{
† More detailed information about the work of Gudran at El-Max fisherman village can be found on their website; http://gudran.com/main/
} 
upgrade development project. Awareness of its potentials must first be addressed to locals to come up with suitable solutions according to their needs.

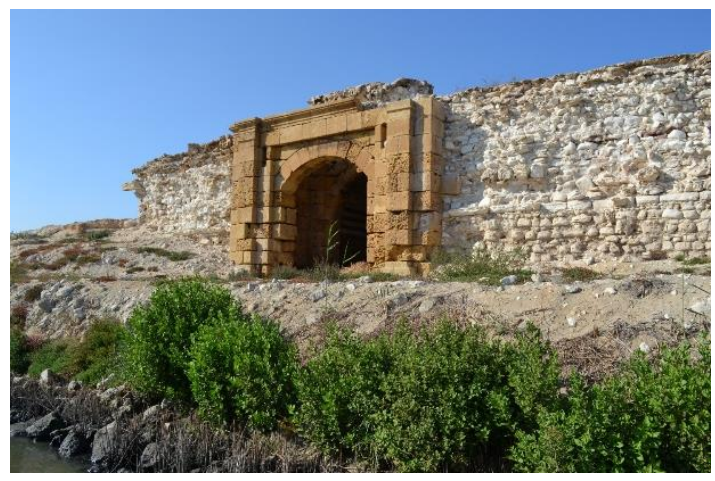

Fig. 4. Archaeological Fortress of El-Max Source: Authors

\section{B. Industrial Heritage Building}

Through site investigation, authors discovered an abandoned old, yet significant industrial building. It is situated on a bridge across the canal at its end towards the south, just before the canal joins the Marriott Lake as shown in Fig. 5. This vacant building can be adaptively reused, and the community can gain economic and heritage conservation characteristics besides fishing.

The industrial building and the fortress are both considered hidden, yet potential assets to the community. For example, the building can be reused as a fish restaurant and cafe overlooking a natural mangrove habitat Fig. 6 . Also, the view of the canal. People can take a tour by boat to reach the place, crossing by the fortress to admire its historical significance and learn of its glory. The building can also become a community centre, to encourage initiatives designed to improve the quality of life and encourage citizens to play their role in the urban environment (Nurul Hidayah Chamhuri H. H., 2015). As a result, it will increase security and sociability concepts (Neda Sadat Sahragard Monfared, 2015), as well as, poverty reduction with the help of public participation in ensuring the quality of life of the urban poor.

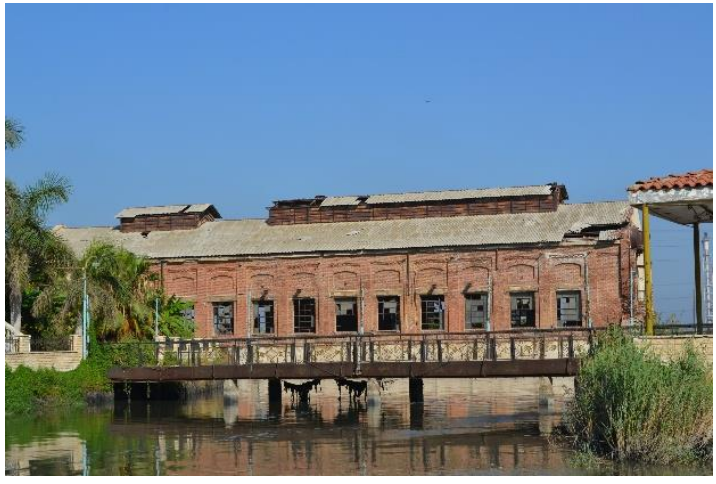

Fig. 5. Industrial Heritage Building Source: Authors

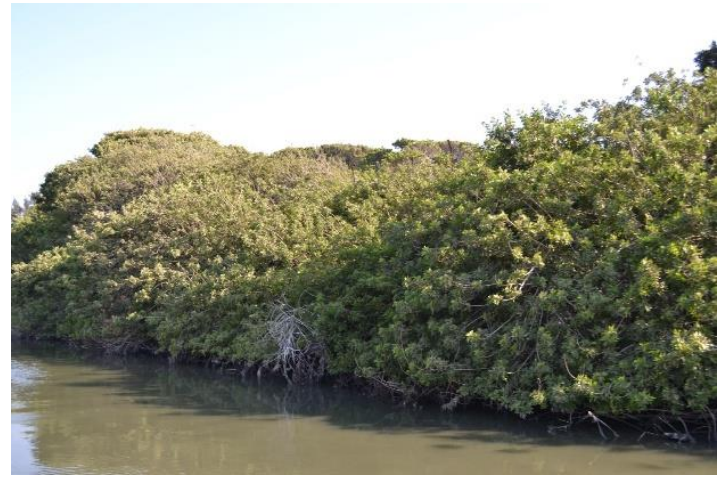

Fig. 6. Natural Mangrove Vegetation on Site Source: Authors 


\subsubsection{Institutional Context and Method of Operation at El-Max area}

The principal stakeholders at El-Max fishermen area include the following; Coastal Guards, Ministry of Defence, Ministry of Water Resources and Irrigation, Ministry of Housing, Ministry of Petroleum and the Ministry of Solidarity, Social Justice, and the local community of El-Max. These institutions all have interests in the area. The Coastal Guards' major concern is national security. The fishermen pose a threat, some of them were caught in illegal activities. They have been involved in smuggling and illegal immigration. With the strategic location on the West harbour connected directly to the sea, making it convenient to participate in this predicament and in particular with the economic decline resulting from the lack of fish in the polluted canal and sea.

It is assumed that by providing support to local fishermen through an urban upgrade project that serves their simple needs (fishing nets, boat maintenance, permission to fish in the Mediterranean, canal water purification, and a community centre); this will eliminate the negative social behaviour. Thus, ensuring the security of the harbour and eliminating all illegal activities, while creating a positive outcome in the area and the city. To enhance their quality of life, investment in micro-enterprises that reflect the unique nature and character of the area, such as; fish restaurants, cafes, fishing crafts and marine touristic activities.

Considering the simple requirements for the upgrade of El-Max, the action plan can begin by facilitating four main issues: 1. Forbidding petroleum companies to dispose of industrial waste in the canal. 2. Establishing a community centre for them to discuss and solve their problems. 3. Addressing the Coastal Guards to provide fishing authorization with full observation. 4. Granting the fishermen long term leases and beneficial rights of the area in return for services and maintenance (Nassar, Naguib, ElFakharany, \& Kamel, 2014).

Unfortunately, the local government has neglected the problems of El-Max fishermen for many years, holding no future development plans for the area.

While conducting the study, authors acquired latest updates from the local government of Alexandria. According to A. Shawky $\ddagger$, the government will intervene to resolve the problems of El-Max fishermen shortly. The ministry of water resources and irrigation is now working on a big project in the Marriott Lake, and it proposes to widen the two canals at El-Max to dispose of the increase in water level from the lake out into the sea through a new water pumping station. The project will result in widening the canal and raising the water level by 2.7 meters. The accelerated water current of the canal will lead to destroying the soil beneath the buildings that are adjacent to the canal. Their structural status is at risk considering the threats of rising water level. The urgent demand to relocate the fishermen community into a safer place is mandatory. The local government in Alexandria confined a total of 230 affected families respectively.

According to the Informal Settlement Development Facility (ISDF), this informal community is now a lifethreatening area graded number two because of its geological and environmental risk. Therefore to ensure the protection and livelihoods of the locals, they are scheduled to be transferred to state-owned housing units in November 2016.

After state negotiations with the newly established fishermen society of El-Max, they came to an agreement of removing the fisherman accommodation units and relocating the affected 230 families away to better homes. However, more issues are remaining to be solved; where to put their boats and store their fishing gears. The local government in return assures the construction of storage units for their equipment. The canal banks will also have a docking platform for their boats.

Eight apartment buildings with 160 available units will be provided, located just east of the canal. After the water level has been stabilised, the government will use the remaining space on the banks of the canal in commercial and touristic activities to take advantage of the canal view.

It is assumed that by providing support to local fishermen through an urban upgrade project that serves their simple needs (fishing nets, boat maintenance, permission to fish in the Mediterranean, canal water purification, and a community centre); this will eliminate the negative social behaviour. To enhance their quality of life, investment in

$\ddagger$ Mr. A. Shawky- Chief Financial Officer in slums administration- Alexandria Governorate. 
micro-enterprises that reflect the unique nature and character of the area, such as; fish restaurants, cafes, fishing crafts and marine touristic activities.

The significance of the project from the Ministry's point of view is to ensure the security of the harbour and the elimination of all illegal activities while creating a positive outcome in the area and the city.

Considering the financial aid is comparatively low. Therefore, if the government is motivated to carry out the urban development, the action plan would begin by facilitating the above four main issues.

\section{Recommendations}

\subsection{Proposed Urban Upgrade Program for El-Max Fishermen Village}

In pursuance of sustainable development, a community integrated design approach can be adapted to achieve the effective urban upgrade. This approach is obtained through the economic, social, and environmental development of El-Max Fishermen Village. To achieve economic development; micro-enterprise investment will help create job opportunities for the locals. In addition to the income gained from becoming a touristic attraction on the local, national and international levels.

Providing security for tenants and occupants by presenting beneficial land rights for the local fishermen (legalising their situation), assists in social development. As well as introduce the concept of Post Occupancy Evaluation (POE) as a safety performance and occupants' satisfaction assessment tool (Husrul Nizam Husina, 2015). El-Max fishermen community is recognised for its unique urban fabric which constitutes its identity. Therefore, any services or buildings added should keep that in perspective to ensure social cohesion and engagement.

With regards to environmental sustainability; ensuring marine and plant life by the reduction of industrial pollution, constant environmental impact assessment, and evaluation, as well as, introducing energy efficiency and water conservation techniques through public awareness campaigns.

\subsection{Community Driven Development Approach}

Community Driven Development (CDD) programs are guided by principles of clarity, social inclusion, community empowerment, requires participation and responsiveness, local accountability, and enhanced local capacity (Wong, 2012). Recent studies have shown that when provided with concise and clear guidelines, accessibility to information, sufficient local abilities, and financial aid; members of the community can effectively identify their needs and propose solutions for their problems in cooperation with local authorities and supporting organisations. CDD approaches and actions have been recognised by the World Bank for their fundamental principles of an effective poverty reduction and sustainable development strategy, where urban poverty should be treated more as relative poverty and distributional issues (Nurul Hidayah Chamhuri H. A., 2012).

Despite the advantages of CDD approaches, studies have listed the following as challenges and limitations that require attention in the design and implementation process of CDD projects:

New models of implementation, which require adaptive legal frameworks and systems to ensure sustainable development.

Convergence with sector programs and formal decentralisation offering an efficient local urban development base that support the principles of the approach into the entire sub-national governance system.

Urban applications to varying local contexts, even participation, is considered essential in the urban upgrade of slums.

By supporting the locals' livelihoods through providing essential services and public investments. Moreover, due to CDD's growing demand in middle-income urban contexts; further analysis is required to provide the conditions for its success. 
Therefore, in the application of this approach, the previous challenges should be kept in mind during the planning phase, conducting phase and applying phase to ensure achieving the goals of sustainable development.

\section{Conclusion}

The framework for Urban Management Programs is used to establish urban development strategies to improve the capacity of municipal authorities further to implement participatory management mechanisms.

A framework where stakeholders can be approached and dealt with from an institutional aspect. Firstly, the Ministry of Solidarity and Social Justice would be advised to establish El-Max Fishermen Association / El Max Fishermen community centre. This association will grant the opportunity to discuss and solve problems without having to resort to higher authorities. As for the Ministry of State for Environmental Affairs with the Alexandria Petroleum Company (APC), it is recommended to follow the international modern technology to reduce pollution and implement the environmental management policy. Moreover, finally, the Coastal Guards in Alexandria and Ministry of Defence contribute by allowing fishing permits in the sea with constant supervision over any smuggling and illegal immigration activities.

Throughout the process of development, some challenges will appear when executing the proposed idea of an urban upgrade through a community-driven approach based on local needs and managed potentials. However, putting that aside and following stereotypical state solutions to informal settlement problems will deprive local fishermen their sense of belonging.

Sustainable development of El-Max Fishermen Village can be as follows:

From an environmental stance, air pollution treatment plan using filters as well as restrictions and policies that prohibit industrial pollution. A buffer zone or green corridor can be proposed to separate the industrial and residential areas. A sewage treatment plan for the entire sector, in addition to the use of locally grown native aquatic plants on the banks' of the canal to assist in the purification of water from contaminants. Restoring the canal's ecology is considered vital for the livelihood of the fishermen to encourage the growth of fish habitats. Finally, maintaining the natural habitat on site to use it as a sightseeing tour and attraction point, making use of the fortress and the abandoned industrial building to support touristic, commercial and recreational activities suitable for the area.

Physical outcomes of development would constitute the upgrade of the existing urban gaps and opening up new community spaces. Provision of essential supplies and services essential to the standard quality of life (such as health care unit, fish market, bazaar shop, public coffee shops, security kiosks, fish restaurant, playground, mosque, boat maintenance workshops and water transportation). The rehabilitation of buildings; structure, infrastructure, finishing and living conditions. Upgrading the pedestrian network, adjusting the roads for emergency access and construction of a structurally stable boat harbour. As well as, proposing a future extension plan for the population growth. As a response to the government proposal stated earlier in the institutional context section, it would be advised temporarily to relocate the locals in the suggested state-owned property until the water level stabilises. Removal of only units affected by the water level rise will be compensated in the developed master plan of the area to maintain its identity and urban fabric. After which, the proposed urban upgrade supporting the community-driven approach is carried out to ensure the satisfaction of locals and achieving sustainability goals.

Overall, critical reviews provide evidence which suggests that Community-based and -driven development projects are best undertaken in a context-specific manner, with a long time horizon and with careful, well-designed monitoring and evaluation systems (Mansuri \& Rao, 2004).

\section{Acknowledgment}

The authors wish to acknowledge Prof. Dr. Mohsen Bayad - Professor of Architecture at Faculty of Fine Arts for his guidance and support. Also, Arch. Ingy Naguib \& Arch. Ahmed El-Fakharany; both teacher assistants at Pharos University in Alexandria, for their efforts in the field study. Not to forget, Arch. David Ashraf for taking photographs of the area. All of these scholars have provided the authors with valuable information regarding El-Max Fishermen Village. 


\section{References}

(GOPP), G. O. (2012). SUP Alexandria 2032. Alexandria: General Organization of Physical Planning (GOPP).

Aref, Y. G. (2007). Alexandria's Forgotten Architecture - Defensive buildings of Alexandria. First Euro Mediterranean Regional Conference, Traditional Mediterranean Architecture. Present and Future. Barcelona: Rehabimed.

Bruce Ferguson, J. N. (2003). A financial framework for reducing slums: lessons from experience in Latin America. Environment and Urbanization, 201-215.

Harlina Mohamad Ali, M. M. (2012). Self-Sufficient Community through the Concepts of Collective Living and Universal Housing. Procedia Social and Behavioral Sciences, 615-627.

Hazlina Hamdan, F. Y. (2014). Social Capital and Quality of Life in Urban Neighborhoods High Density Housing. Procedia - Social and Behavioral Sciences, 169-179.

Husrul Nizam Husina, A. H. (2015). Correlation Analysis of Occupants' Satisfaction and Safety Performance Level in Low Cost Housing. Procedia - Social and Behavioral Sciences, 238-248.

Ibrahim, A. A. (2012). A Decision Making Approach for Prioritizing Local Communities' Development Investments. Procedia - Social and Behavioral Sciences, 649-660.

ISDF. (2012). About Us: The Informal Settlement Development Facility. Retrieved from The Informal Settlement Development Facility Web site: http://www.isdf.gov.eg

Jamalunlaili Abdullahab, C. B. (2015). Public Participation in the Kuala Lumpur Draft City Plan 2020. Procedia - Social and Behavioral Sciences, 70-75.

Khalifa, M. A. (2011). Redefining Slums in Egypt: Unplanned versus unsafe areas. Habitat International, 40-49.

Mansuri, G., \& Rao, V. (2004). Community-Based and -Driven Development: A Critical Review. Oxford Journals, 1-34.

Nassar, D., Naguib, I., ElFakharany, M., \& Kamel, M. (2014). Project Identification Sheet. Sustainable Cities of the Mediterranean: Guiding Light from Alexandria. Alexandria: Bibliotheca Alexandrina.

Neda Sadat Sahragard Monfared, H. H. (2015). Design principles in Sustainable Local Community with Security and Socialization Approach (Case study: Chizar). Procedia - Social and Behavioral Sciences, 62-70.

Nurul Hidayah Chamhuri, H. A. (2012). Conceptual Framework of Urban Poverty Reduction: A review of Literature. Procedia - Social and Behavioral Sciences, 804-814.

Nurul Hidayah Chamhuri, H. H. (2015). Conceptual Framework of Public Participation in Ensuring Quality of Life of the Urban Poor in Malaysia. Procedia - Social and Behavioral Sciences, 349-356.

Payne, G. (2005). Getting ahead of the game: a twin-track approach to improving existing slums and reducing the need for future slums. Environment and Urbanization, 135-146.

Poor, S. J. (2015). Participation, Sense of Home, and End-users' Needs in Mass Housing. Procedia - Social and Behavioral Sciences, 286-296.

Wong, S. (2012). What have been the impacts of World Bank Community-Driven Development Programs? Washington: The World Bank. 